Clim. Past, 9, 1309-1319, 2013

www.clim-past.net/9/1309/2013/

doi:10.5194/cp-9-1309-2013

(C) Author(s) 2013. CC Attribution 3.0 License.

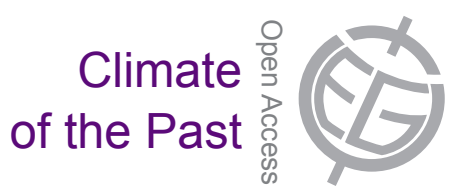

\title{
Dynamic diatom response to changing climate 0-1.2 Ma at Lake El'gygytgyn, Far East Russian Arctic
}

\author{
J. A. Snyder ${ }^{1}$, M. V. Cherepanova ${ }^{2}$, and A. Bryan ${ }^{1}$ \\ ${ }^{1}$ Department of Geology, Bowling Green State University, Bowling Green, OH 43403, USA \\ ${ }^{2}$ Institute of Biology and Soil Science, FEB RAS, 159 Prospect 100-Letiya, 690022 Vladivostok, Russia
}

Correspondence to: J. A. Snyder (jasnyd@ bgsu.edu)

Received: 15 August 2012 - Published in Clim. Past Discuss.: 18 September 2012

Revised: 1 May 2013 - Accepted: 17 May 2013 - Published: 24 June 2013

\begin{abstract}
The Lake El'gygytgyn sediment record contains an abundant diatom flora through most intervals of the lake's history, providing a means to create and test hypotheses concerning the lake's response to changing climates. The 0 1.2 Ma core interval is characterized by shifts in the dominant planktonic genera and events of exceptional concentration and diversity. Warm interglacial intervals have enhanced concentration and diversity of the plankton. This response is most extreme during exceptional events corresponding to marine isotope stages (MIS) 11 and 31. Diatom concentration and diversity also increase during some cold intervals (e.g., MIS 2), suggesting conditions of lake circulation and nutrient cycling promoting diatom production during these events. Short intervals of low plankton concentration accompanied by shifts in the dominant genus of the lake suggest conditions during certain cold events generate a severe impact on plankton production. The absence of these events during extended intervals of low summer insolation variability suggests a muted cold-event response of the lake system linked to regional climate.
\end{abstract}

\section{Introduction}

The sediment record from Lake El'gygytgyn, Far East Russian Arctic, contains a unique archive of terrestrial paleoclimate spanning the last 3.6 million years (Melles et al., 2012). The majority of recovered sediment contains significant but variable biogenic silica (Meyer-Jacob et al., 2013) mostly in the form of diatom valves. Understanding the factors influencing the production and preservation of diatoms in the lake is one key to understanding many of the other proxy records used to unravel the response of the ancient lake system to changing climates. Diatom species assemblages also offer a powerful recorder of changes in the lake potentially linked to paleoclimate through ice conditions, circulation, nutrient delivery, and water chemistry (e.g., Smol, 1988; Douglas and Smol, 1999).

Early research on the modern diatom flora in El'gygytgyn has focused on descriptions of extant taxa found in lakebottom samples. These first studies describe many unique species, consistent with a long-lived lake system (Sechkina, 1956; Jóuse and Sechkina, 1960; Kharitonov, 1980, 1993; Genkal and Kharitonov, 1996, 2005, 2006). Prospects of the recovery of the complete sediment record have inspired a renewed interest in the modern diatom flora (Cremer and Wagner, 2003; Cremer et al., 2005; Cremer and van de Vijver, 2006; Stachura-Suchoples et al., 2008). However, because of its remote location, on-site studies have been only short duration, and the diatom response to interannual changes in the lake system is poorly constrained.

Previous diatom studies of sediment cores from Lake El'gygytgyn show a generally abundant, diverse, and variable flora. The core PG1351 record included 150 samples spanning the last $250 \mathrm{ka}$ (Cherepanova et al., 2007, 2010). Although these initial investigations demonstrated the potential of these diatom records, the interpretations from these early core studies were complicated by the presence of turbidites and by taxonomic uncertainty, especially in the morphologically variable dominant planktonic diatom included in the Cyclotella ocellata complex (sensu Cremer and Wagner, 2003).

This study utilizes samples from a more recent core (Lz1024; recovered in 2003 extending to $340 \mathrm{ka}$ ) and initial 
samples from the nearby deep drilling site (5011-1) to construct a continuous low-resolution composite record spanning the last 1.2 Ma. Four intervals are analyzed in finer temporal resolution, corresponding to marine isotope stages (MIS) $1,5 \mathrm{e}, 11$, and 31, to contribute to the research focus on exceptional interglacial events (Melles at al., 2012; Lozhkin and Anderson, 2013; D'Anjou et al., 2013; Vogel et al., 2012) and to help understand conditions during the local Last Glacial Maximum (Holland et al., 2013). This study provides initial interpretations of these diatom records along with guidance and prospects for future investigation.

\subsection{Setting}

Lake El'gygytgyn $\left(67^{\circ} 30^{\prime} \mathrm{N}, 172^{\circ} 5^{\prime} \mathrm{E}\right.$; Fig. 1) is situated in an impact crater dated $3.58 \pm 0.04 \mathrm{Ma}$ (Layer, 2000). The modern lake (12 km diameter and $175 \mathrm{~m}$ deep) is oligotrophic (Nolan and Brigham-Grette, 2007). In recent observed years, the lake is ice free during the period of approximately JulyOctober and completely mixes in summer. Weak sub-ice convection is also suggested by gas bubble patterns in the lake ice (Nolan and Brigham-Grette, 2007). At the present lake level, a shallow shelf (less than $10 \mathrm{~m}$ deep) occupies approximately $11 \%$ of the lake basin area (Nolan and BrighamGrette, 2007). However, morphological evidence suggests higher and lower lake levels in the past, substantially impacting the area of shallow-water lake bottom (Fedorov et al., 2008; Juschus et al., 2011). Additional details of the modern setting and limnology are described elsewhere (Nolan and Brigham-Grette, 2007; Fedorov et al., 2012; Nolan, 2012; Nolan et al., 2012; Wennrich et al., 2013).

\section{Methods}

Diatom samples were prepared from a measured mass of freeze-dried sediment, treated with boiling $30 \% \mathrm{H}_{2} \mathrm{O}_{2}$. Systematic diatom counts were conducted at $1000 \times$ magnification with a Leica DMLB light microscope with differential interference contrast. At least 500 valves were counted in all but a few sparse samples. Quantitative diatom concentrations were calculated using measured transect areas on slides prepared from a measured sediment mass and added calibrated microspheres settled through a water column onto a microscope cover slip (modified from Battarbee et al., 2001).

Counted diatoms were identified to species level, wherever possible, using a wide variety of taxonomic references. Taxonomy of the dominant diatoms was confirmed by scanning electron microscopy of selected samples. Names assigned to the taxa are generally those used by previous El'gygytgyn investigators (e.g., Sechkina, 1956; Cremer and Wagner, 2003; Cherepanova et al., 2007; Stachura-Suchoples et al., 2008). Presentation and discussion of planktonic diatoms in this study focus on genus-level variations. In most cases, each genus is dominated by a single species as noted

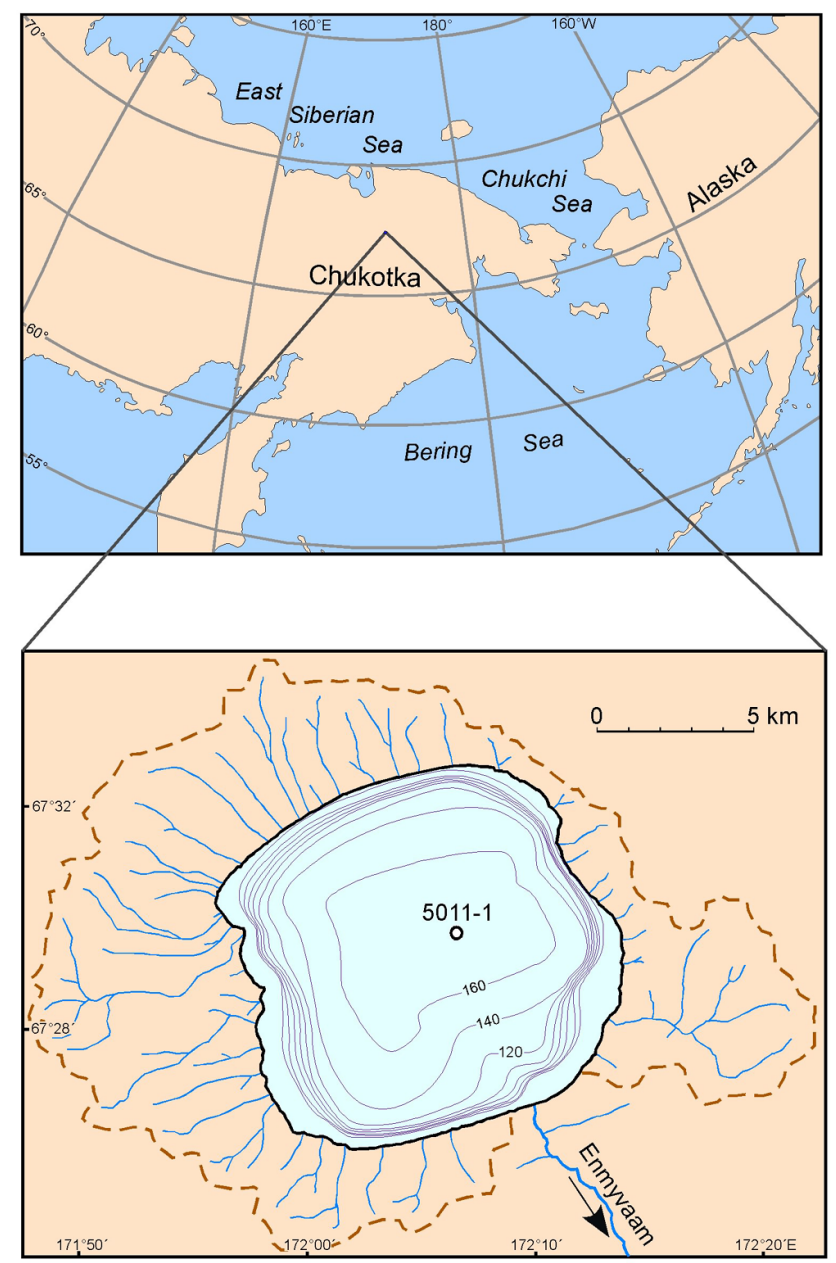

Fig. 1. Location map of Lake El'gygytgyn and its catchment. Bathymetry ( $20 \mathrm{~m}$ contour interval) and stream network are modified from Nolan and Brigham-Grette (2007).

in the text. Cyclotella contains multiple morphotypes which, with further taxonomic work, will warrant further subdivision. Here they are combined in the Cyclotella ocellata complex (Cremer and Wagner, 2003) because of the difficulty to distinguish these taxa in routine counts. Aulacoseira subarctica (O. Müller) Haworth is the dominant member of its genus. Minor occurrences of other Aulacoseira species also occur and are excluded from the Aulacoseira plots. Genuslevel diversity in the plankton was estimated utilizing the Shannon index (e.g., van Dam, 1982). Further observations of periphyton assemblage, valve size and preservation were noted and quantified in certain cases.

The age model for the Lz1024 core is provided by methods described elsewhere (e.g., Juschus et al., 2007). Below $340 \mathrm{ka}$, the chronology is based on the detailed age model derived primarily from paleomagnetic reversal and orbital tuning (Melles et al., 2012) and correlation to the base of the Lz1024 record. The initial analysis interval presented here provides an approximately $4-5 \mathrm{kyr}$ average resolution for the 
$0-1.2 \mathrm{Ma}$ record and $1 \mathrm{kyr}$ resolution for the intervals analyzed in more detail.

Diatom accumulation rates (valves $\mathrm{cm}^{-2} \mathrm{kyr}^{-1}$ ) are calculated from concentrations in individual samples (valves $\mathrm{g}^{-1}$ ) using age model sediment accumulation rates and dry bulk density calculated from gamma ray attenuation porosity evaluator (GRAPE) scans (Gebhardt et al., 2013) and are presented for some core intervals. The main results are presented as simple concentrations to describe independently the occurrence of diatoms in the sediment and to avoid introducing uncertainties related to the age model.

\section{Results}

\subsection{The composite record 0-1.2 Ma}

The $0-1.2 \mathrm{Ma}$ record presented here preserves a complex cyclicity in the lake's diatoms, reflected in the concentration, preservation, valve size, and species assemblage (Fig. 2). Because of the great differences in size, silica content, and valve concentration in dominant planktonic diatoms and the sporadic occurrence of some other planktonic taxa, absolute concentrations, rather than percentage within an assemblage, are presented for comparison. Numerical valve counts of total diatoms show a broadly similar trend to the biogenic silica record (Frank et al., 2012; Meyer-Jacob et al., 2013). Subtle differences in these trends may be attributed to minor variation in valve size and preservation observed in these intervals and by contributions from larger, less numerically abundant taxa.

The most notable down-core changes are shifts in the dominant genera. Pliocaenicus seczkinae Stachura-Suchoples, Genkal et Khursevich, previously observed to emerge since $15 \mathrm{ka}$, has a long complex history in El'gygytgyn, exhibiting substantial morphological variability. Cyclotella likewise becomes a minor component of the plankton during certain intervals. During other times, both diatoms co-exist, as in the Holocene.

One clear aspect of the $0-1.2 \mathrm{Ma}$ diatom record is the occurrence of intervals of exceptional diatom concentration that correspond to inferred warm intervals (yellow in Fig. 2). Both plankton and periphyton concentrations increase, and the valves exhibit better preservation. Other planktonic taxa including Stephanodiscus cf. minutulus (Kützing) Cleve and Möller also occur during some of these events. A. subarctica occurs in abundance during some of these events prior to $550 \mathrm{ka}$, and is the numerically most abundant taxa during particular intervals from 800 to $1200 \mathrm{ka}$. The most extreme of these exceptional events correspond to MIS 11 and MIS 31 . Here both total plankton and periphyton reach concentration peaks unmatched in the studied interval, and a high diversity of planktonic diatoms occurs. Many of the high diatom concentration events are characterized by temporary size increases in the morphologically plastic planktonic genera (especially Cyclotella and Pliocaenicus). For example, during MIS 11 the initial cell diameter of Cyclotella is 25-30 $\mu \mathrm{m}$, compared to $15-20 \mu \mathrm{m}$ during inferred colder intervals immediately preceding and following this event. During MIS 31 the initial cell diameter of Pliocaenicus increases to $35-50 \mu \mathrm{m}$ from less than $30 \mu \mathrm{m}$ before this event.

A few intervals of increased plankton and periphyton abundance correspond to apparently cold intervals (purple in Fig. 2). These are distinguished by their distinctive periphyton assemblage, particularly the absence of species found in inferred warm intervals, especially Achnanthidium kriegeri (Krasske) Hamilton, Antoniades et Siver and Cocconeis placentula Ehrenberg (see Sect. 3.2). None of these intervals is characterized by significant concentration of Pliocaenicus.

Short $(<20 \mathrm{~cm})$ intervals of low plankton abundance also occur in the diatom record. Seven of the 234 samples systematically analyzed for this study contain less than $10^{7}$ valves $\mathrm{g}^{-1}$ of total planktonic diatoms (green in Fig. 2). Some of these samples have zero observed planktonic diatoms or an order-of-magnitude-lower concentration than any other samples. Corrections for age model sedimentation rate and density confirm exceptionally low diatom accumulation rates. Many of these zones have persisting moderate concentrations of well-preserved periphyton. These intervals, in many cases, correspond to shifts in the dominant plankton in the lake. For example, at $924 \mathrm{ka}$ Pliocaenicus replaces Cyclotella. One such zone occurs at $225 \mathrm{ka}$. Although Cyclotella persists, this interval corresponds to an abrupt decline in a morphotype of the Cyclotella ocellata complex (Cherepanova et al., 2010), which dominates the plankton 225-550 ka. This long-term dominance and abrupt decline may justify the establishment of this morphotype as a separate distinct species.

\subsection{MIS 1 and 2 (0-34 ka)}

The genus Cyclotella dominates the sediment record of the last $34 \mathrm{ka}$ (Fig. 3). Minor and sporadic planktonic diatoms vary dramatically across this portion of the record. The 20 $25 \mathrm{ka}$ interval exhibits the greatest diversity in plankton with peaks in Fragilaria cf. nanana Lange-Bertalot, S. cf. minutulus, and Asterionella formosa Hassal often associated with higher nutrient concentrations (e.g., Lotter et al., 1998; Bennion et al., 2004). This interval corresponds to the highest $\mathrm{Si} / \mathrm{Ti}$ ratios and biogenic silica concentrations in the last $34 \mathrm{ka}$, some intervals exceeding $30 \%$. Average diatom accumulation rates of 20-25 ka approximately equal the average from $0-5 \mathrm{ka}\left(1.8 \times 10^{10}\right.$ valves $\left.\mathrm{cm}^{-2} \mathrm{kyr}^{-1}\right)$. The comparatively large, heavily silicified Pliocaenicus occurs in abundance only since $15 \mathrm{ka}$, although a few individual valves are observed on slides from earlier samples.

The periphyton species assemblage also changes with comparable timing. Small Achnanthaceae are numerically the most abundant valves in most samples. A. kriegeri and Achnanthidium minutissimum (Kützing) Czarnecki occur in greatest abundance since $15 \mathrm{ka}$. In contrast, Planothidium 


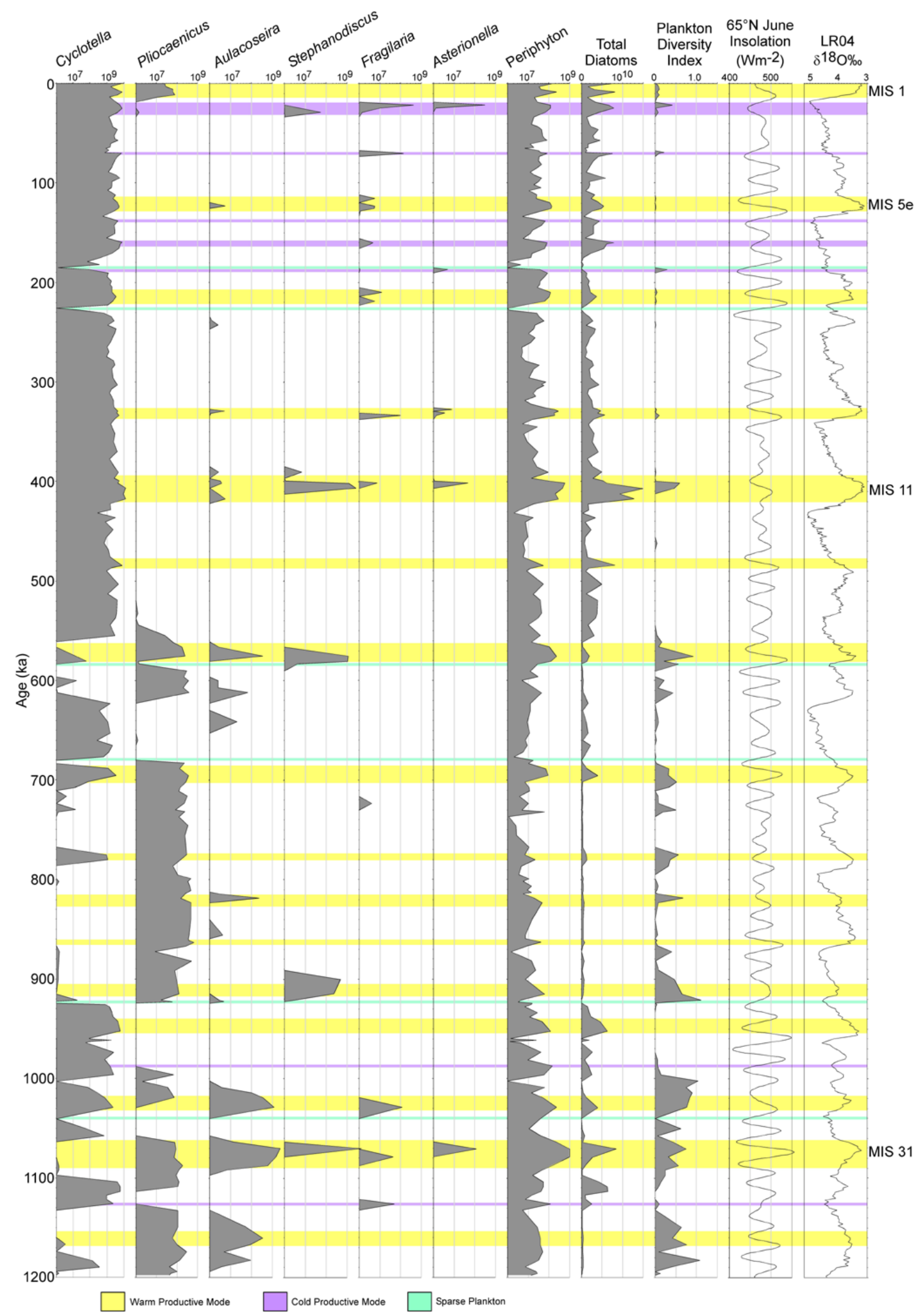

Fig. 2. Concentration (valves $\mathrm{g}^{-1}$ ) of planktonic species, total periphyton, total diatoms, and plankton diversity (Shannon index) from 0 to 1.2 Ma. Exceptional events are indicated by colored intervals. Diatom concentrations, except total diatoms, are plotted on a log scale. For comparison, the marine isotope stack (Lisiecki and Raymo, 2005) and 65 $\mathrm{N}$ June insolation (Laskar et al., 2004) are also plotted. 


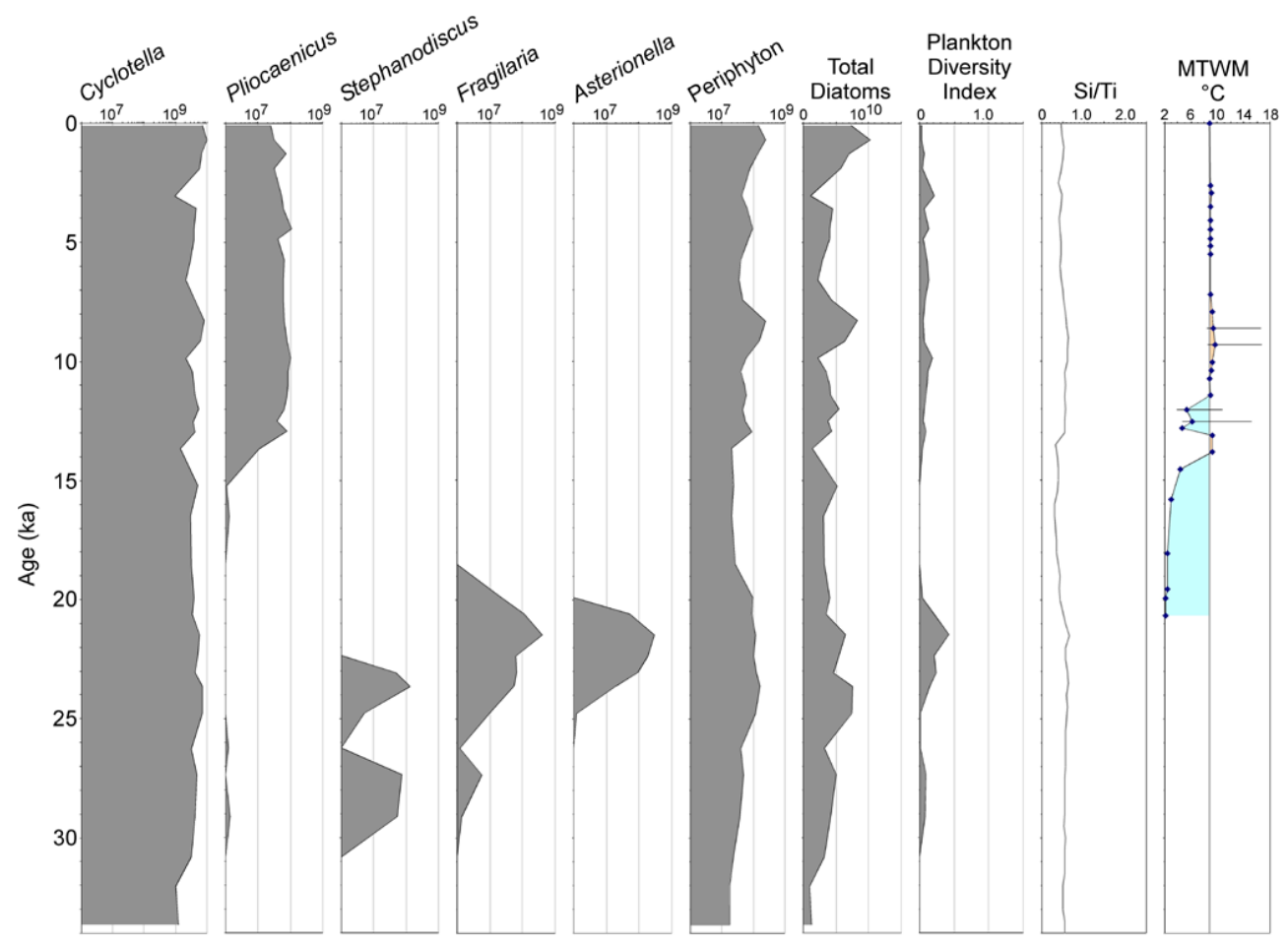

Fig. 3. Concentration (valves $\mathrm{g}^{-1}$ ) of planktonic species, total periphyton, total diatoms, and plankton diversity (Shannon index) from $0-$ $34 \mathrm{ka}$. For comparison, other El'gygytgyn climate proxies including Si / Ti measured by XRF core scanning and MTWM (mean temperature warmest month) derived from pollen data (best modern analog approach) (Melles et al., 2012). Other pollen data (Lozhkin et al., 2007) suggest continuation of a cold assemblage through the 20-34 ka interval (not shown).

oestrupii (Cleve-Euler) Round et Bukhtiyarova peaks from 19 to $24 \mathrm{ka}$. Diatoms with valves greater than $75 \mu \mathrm{m}$ length vary more irregularly. However, Frustulia rhomboides var. amphipleuroides (Grunow) DeToni is almost exclusively observed $15-25 \mathrm{ka}$, and Eunotia pseudopectinalis Hustedt is more characteristic of the interval since $15 \mathrm{ka}$.

\subsection{MIS 5e (111-135 ka)}

The genus Cyclotella also dominates the 111-135 ka core interval (Fig. 4). Sparse Pliocaenicus and planktonic Fragilaria occur in a few samples. The inferred peak warmth of MIS 5e corresponds to an approximate doubling of the diatom concentration driven mostly by Cyclotella. Calculated genus-level plankton diversity does not significantly increase in this interval. This index may underestimate the true plankton diversity in this interval because the dominant Cyclotella contains at least two morphotypes with significantly different diameter. The peak in diatoms seen at $135 \mathrm{ka}$ corresponds to the preceding cold productive mode (Fig. 2).

\subsection{MIS 11 (360-430 ka)}

The interval corresponding to MIS 11 exhibits the greatest peak in diatom concentration driven mostly by Cyclotella (Fig. 5). During the first part of this interval (411-416 ka) peak abundance corresponds to numerically abundant but small-diameter Cyclotella and Stephanodiscus. From 411 to $400 \mathrm{ka}$, Cyclotella occurs in lower abundance but increased size. Diversity also increases significantly in this interval, especially 401-403 ka, where Fragilaria and Asterionella peak.

\subsection{MIS 31 (1057-1113 ka)}

The interval corresponding to MIS 31 peak warmth contains a diatom abundance second only to MIS 11 in the $0-1.2 \mathrm{Ma}$ record (Fig. 6). Aulacoseira is the most consistent and numerically abundant member of the plankton assemblage. The robust Pliocaenicus, although numerically less abundant, is also a significant and consistent part of the assemblage. Similar to MIS 11, additional genera occur in the more recent portion; in this case Stephanodiscus and Asterionella occur 1065-1076 ka. Above this interval there is a low plankton abundance zone $\left(<10^{7}\right.$ valves $\left.\mathrm{g}^{-1}\right)$ corresponding to the extirpation of Pliocaenicus and return of Cyclotella to dominance in the lake. This low-abundance zone is missed in the 0-1.2 Ma record because of the lower sample resolution, although it is suggested by the observed shift in dominant genus. 


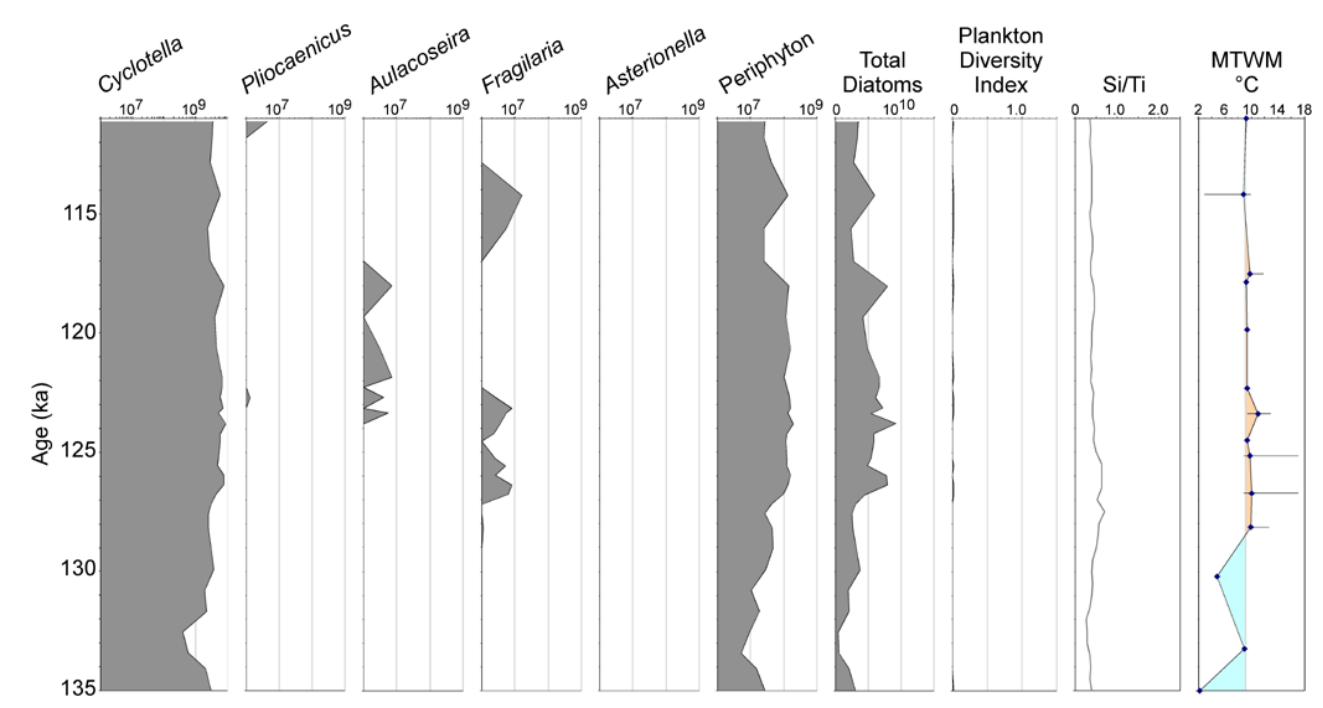

Fig. 4. Concentration (valves $\mathrm{g}^{-1}$ ) of planktonic species, total periphyton, total diatoms, and plankton diversity (Shannon index) from 111 to $135 \mathrm{ka}$. Other El'gygytgyn climate proxies from Melles et al. (2012) are included for comparison (see Fig. 3).

\section{Discusssion}

\subsection{Peak warmth intervals}

Observing the Holocene and other identified interglacial intervals from the composite core record, a clear pattern in diatom response is apparent. Concentration increases in both periphyton and plankton. Genus-level diversity increases in the plankton. Valves are generally well preserved with only minor dissolution noted. The occurrence of certain periphytic taxa also characterizes each of these intervals, especially A. kriegeri and C. placentula. These taxa also occur in the deeper record, even as the dominant plankton varies. In general, the diatom response is consistent with a relatively favorable environment for diatom growth that might be anticipated from enhanced nutrient delivery, prolonged openwater growing season, and expanded diversity in habitats in the lake and its catchment.

The emergence of Pliocaenicus since $15 \mathrm{ka}$ may be a response to warming and enhance open-water conditions. Little is known about the ecological tolerance of this taxon. Flower et al. (1998) speculate the similar Pliocaenicus costatus var. sibiricus (Skabitch.) Round et Håkansson responded favorably to 20th-century warming in Lake Bolshoe, Siberia. The appearance of Pliocaenicus in El'gygytgyn at 15 ka may also partially reflect the elimination of a competitive exclusion from larger members of the Cyclotella ocellata complex. These forms disappear from the record during an inferred cold, diatom-poor interval at ca. $70 \mathrm{ka}$. Thus, favorable conditions for this large, heavily silicified Pliocaenicus may first recur after $15 \mathrm{ka}$, allowing expansion into this vacated niche in the phytoplankton. The linkage between Pliocaenicus abundance and climate is further strengthened by the correspondence with its emergence 13-15 ka, peak at
9-10 ka, and subsequent decline through the Holocene with the pollen-derived summer temperature (Fig. 3) (Melles et al., 2012).

Although not yet quantified in detail, the observed size increase in Pliocaenicus or Cyclotella, particularly in MIS 11 and 31 , may also be a response to conditions during these times. Diatom size control may vary with conditions of a specific lake (e.g., Finkel et al., 2009). In a nutrient-limited lake system, higher nutrients (including silica) may favor larger plankton. Further, larger plankton could be an adaptation to greater mixing/turbulence due to more open water, allowing larger diatoms to remain in the photic zone without sinking. On longer timescales, individual species may adapt to competition introduced during intervals favorable for phytoplankton production. The El'gygytgyn sediment record may provide an exceptional opportunity to explore these phenomena on glacial-interglacial timescales.

Observed interglacials within the $0-1.2 \mathrm{Ma}$ record are highly variable in the magnitude of their diatom response. MIS 11 and 31 are exceptional events both in diatoms and other proxies (Melles et al., 2012). Both intervals have peaks in species usually associated with enhanced nutrient status. The occurrence of these assemblages corresponds to sediments Facies C, sensu Melles et al. (2012), characterized by reddish-brown, finely laminated silt, explained by high productivity in the growing season and anoxic bottom waters during winter. The unique diatom response may result from enhanced nutrient delivery from the catchment or a threshold in lake-water oxygenation and circulation, altering the nature and timing of nutrient cycling in the lake (e.g., Rippey et al., 1997; Brüchman and Negendank, 2004). This exceptional diatom production and accumulation plays an important role in the formation of this sediment facies, ranging between 20 and $50 \%$ biogenic silica during these peaks. 


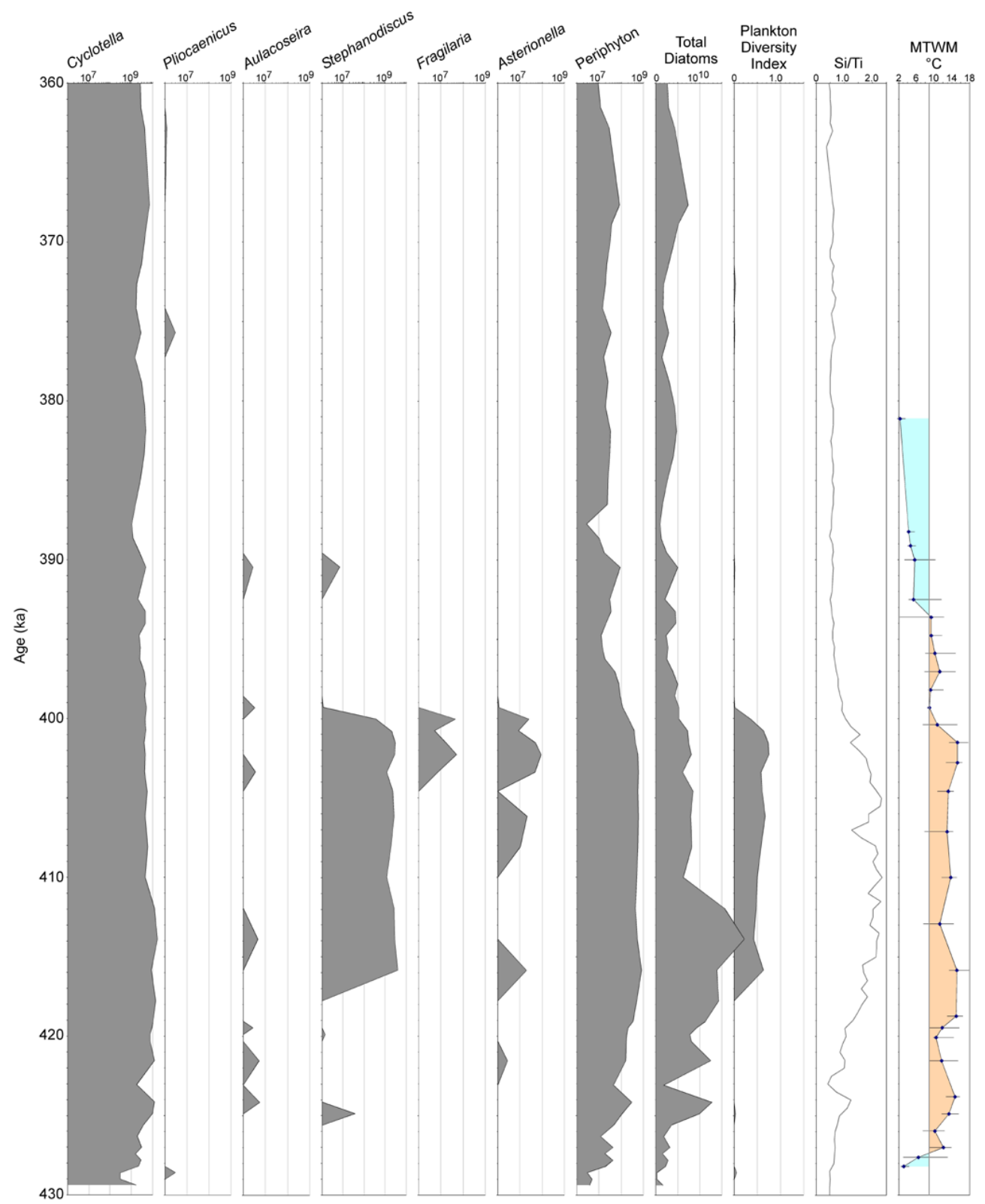

Fig. 5. Concentration (valves $\mathrm{g}^{-1}$ ) of planktonic species, total periphyton, total diatoms, and plankton diversity (Shannon index) from 360 to $430 \mathrm{ka}$. Other El'gygytgyn climate proxies from Melles et al. (2012) are included for comparison (see Fig. 3).

Correlation between the plankton assemblages and other proxy records during MIS 11 and 31 (Figs. 5 and 6) affirms their climate sensitivity. Initial warming at $427 \mathrm{ka}$ (MIS 11 ) is mainly expressed as an increase in Cyclotella. Following modest declines in $\mathrm{Si} / \mathrm{Ti}$ and pollen-derived summer temperature, Stephanodiscus occurs at levels comparable to Cyclotella 400-417 ka. Asterionella also occurs sporadically in this interval. This event corresponds to the peak of MIS 11 , inferred from pollen and biomarker temperature reconstructions (Melles et al., 2012; D'Anjou et al., 2013). These species abruptly decline as reconstructed summer temperatures first approach near-modern values at ca. $400 \mathrm{ka}$. During
MIS 31, initial warming ca. 1085-1090 ka corresponds to the emergence of Aulacoseira as the dominant planktonic diatom. Stephanodiscus and Asterionella similarly rise during the peak in pollen-indicated summer temperature (1076 ka) and abruptly decline at near-modern conditions (1065 ka). This lag further supports the hypothesis of a threshold in climate-driven nutrient conditions in the lake during extreme interglacials.

The distribution of $A$. subarctica, a widespread diatom preferring intermediate nutrient conditions (Gibson et al., 2003), illustrates some of the complexity of comparing particular interglacials. This diatom, occurring almost exclusively in 


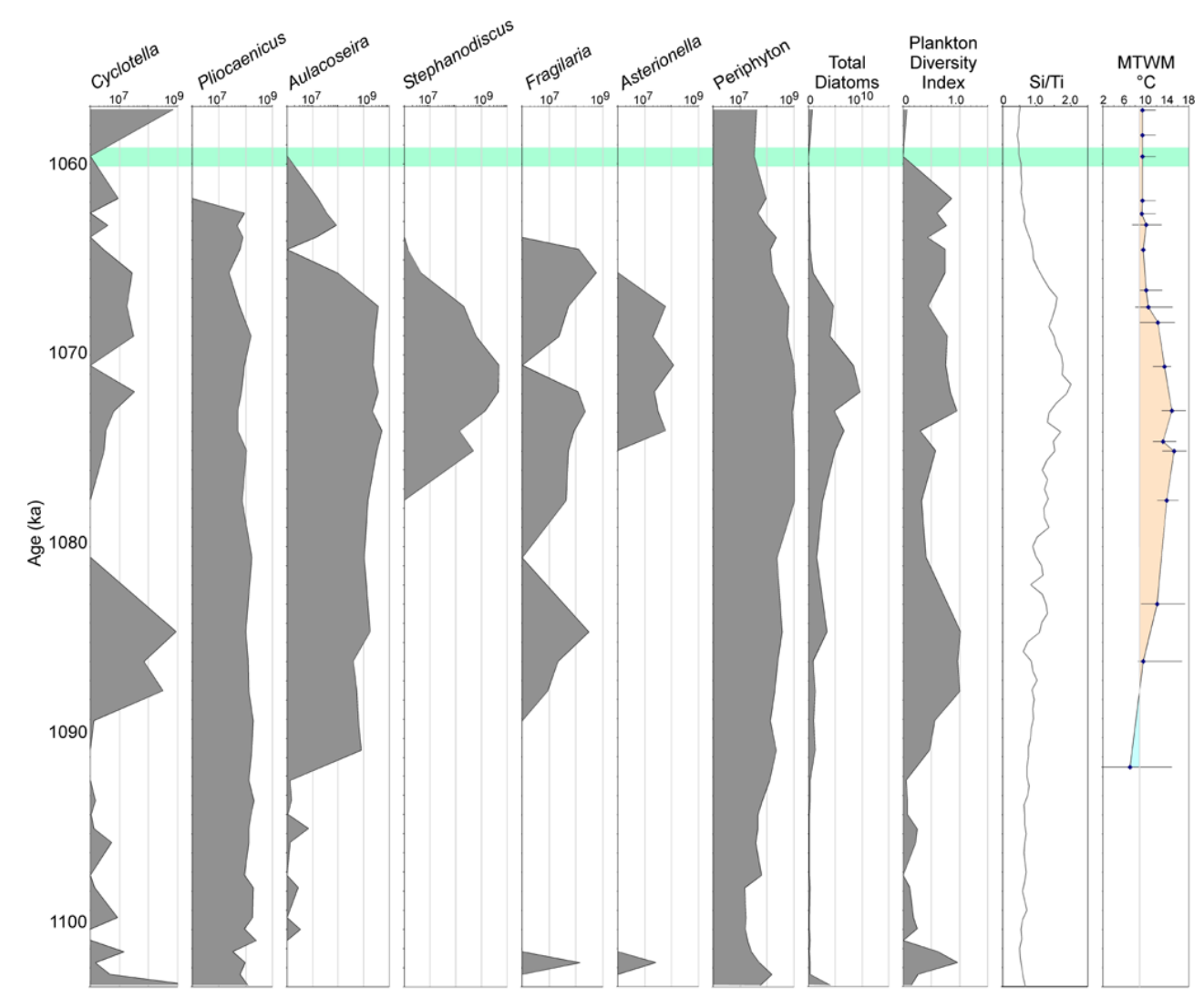

Fig. 6. Concentration (valves $\mathrm{g}^{-1}$ ) of planktonic species, total periphyton, total diatoms, and plankton diversity (Shannon index) from 1057 to $1103 \mathrm{ka}$. Other El'gygytgyn climate proxies from Melles et al. (2012) are included for comparison (see Fig. 3). The green bar indicates a sparse plankton event (compare Fig. 2) not observed in lower-resolution sampling.

identified interglacial intervals, is a minor component since $550 \mathrm{ka}$ but dominates in some intervals between 830 and $1150 \mathrm{ka}$. This species is also abundant in Lake Baikal during approximately this same time, peaking ca. 850,1150, and $1190 \mathrm{ka}$ (Grachev et al., 1998), suggesting a broader biogeographic influence on its occurrence and distribution.

\subsection{Cold productive intervals}

The occurrence of high biogenic silica (20-35\%) and diatom production during MIS 2 may help to decipher the environment of the lake during this interval and to understand the dynamics of the lake system and its response to changing climate. The substantially different overall assemblage, including blooms of delicate planktonic taxa, generally favoring higher nutrient status and not observed in substantial quantities in the Holocene, suggests that this trend is more than a preservation effect or lack of dilution from other inputs. More likely, the environment in the lake was similarly favorable for diatom production compared to the recent lake. Yet other proxies, such as pollen, sediment facies, and diatom isotopes suggest at least $4{ }^{\circ} \mathrm{C}$ colder summer air temperatures compared to modern conditions (Melles et al., 2012; Chapligin et al., 2012), and in other cold stages this diatom response is absent.

Periodic circulation of a mostly ice-covered lake is one hypothesis to generate such production and diversity. Periodic expansion in plankton diversity may reflect adaptation of the dominant species to a more limited range of conditions or periodic changes in nutrient resource distribution (e.g., Kilham et al., 1996). The general dominance of Cyclotella or Pliocaenicus may represent a competitive exclusion of other taxa during the typical range of conditions (e.g., Stoermer and Edlund, 1999). The particular occurrence of these nutrientfavoring phytoplankton species during MIS 2 may indicate conditions providing seasonal to extra-seasonal pulses of nutrients to the plankton, allowing for a temporary increase in the population of these widespread taxa. Circulation-induced seasonal nutrient input timed to persistent transparent ice cover may also promote the expansion of these otherwise sporadically occurring taxa. Such a scenario may also be consistent with the lack of significant Pliocaenicus, perhaps requiring more extensive open-water conditions.

Other observations from the MIS 2 sediment record provide additional perspective on the lake's response to this event. Melles et al. (2012) suggest that the sediment facies indicates more extensive ice cover leading to oxygen-depleted 
bottom waters, but sufficient melting of the lake's margins to allow some fluvial input. However, this sediment Facies A does not always correspond to the diatom response observed in MIS 2. Melles et al. (2007) attribute high total organic carbon in MIS 2 to some combination of increased productivity and preservation due to anoxia. Investigations of biomarkers and organic matter $\delta^{13} \mathrm{C}$ indicate limited connection to atmospheric $\mathrm{CO}_{2}$ and limited oxygen depletion in the water column (Holland et al., 2013) and, although not indicating enhanced aquatic production or nutrients, imply that enhanced production would need to be sustained by internal biogeochemical cycles.

The periphyton assemblage also changes during this same interval, suggesting environmental changes across all diatom habitats. Their abundance suggests at least periodic melting sufficient in the lake margins to promote the diversity and abundance of the lake's periphyton community. The periphyton may respond directly to climate-induced shallow-water habitat changes, or indirectly to suggested nutrient conditions and lowered lake level during MIS 2 (Juschus et al., 2011). However, the uncertain tolerance ranges of the dominant El'gygytgyn periphyton make a specific interpretation of these changes difficult.

Additional short productive intervals (sensu MIS 2) lacking the characteristic interglacial periphyton suggest the potential recurrence of conditions favorable to diatoms during some cold events. Similar to MIS 2, several of these intervals correspond to low insolation and heavy marine oxygen isotopes in the tuned chronology. Thus, interpretations of biogenic silica and diatom concentration in the deeper record may be complicated by additional such events, requiring confirmation with other proxy records.

\subsection{Sparse plankton events}

Events in which plankton dramatically decreases in abundance and subsequently re-emerges with a different character may help to constrain the nature of these intervals of the lake's history. These observations imply that phytoplankton in the lake is stressed such that competitive exclusion is eliminated for some time. However, the recurrence of species either unique to El'gygytgyn or only narrowly distributed over the long history of the lake suggests that minimal populations are sustained in the lake, and that they survive these events. Given the correlation of these events to relatively cold intervals, these extreme declines in the lake's plankton are most easily explained by a prolonged light limitation from extended summer ice and snow cover on the lake. However, the sparse plankton event at 1060 ka corresponds to a zone of near-modern pollen-derived summer temperature and mean annual precipitation (Melles et al., 2012). Thus, any climate-related mechanism to drive these events is either consistent with such conditions or is short lived and unresolvable in the available pollen record. The role of changing lake level in these events cannot be excluded based on the diatom observations. The persistence of well-preserved neartypical periphyton concentration across some of these intervals suggests some shallow-water habitats are maintained during these times.

The low-plankton events are not evenly distributed through the lake record. None has yet been observed from 225 to $550 \mathrm{ka}$ in the low-resolution sampling completed, and none is anticipated based on the apparent stability of the dominant Cyclotella. The interval 680-920 ka also lacks lowplankton zones with a consistent dominance of Pliocaenicus. These intervals both correspond to a time of loweramplitude summer insolation variability (e.g., Laskar et al., 2004), suggesting that these events may be triggered by conditions unique to summer insolation lows. This observation is similar to the interval of sustained high diatom concentration in the Lake Baikal record 370-580 ka (Prokopenko et al., 2002). The lake system and the regional climate are sensitive to intervals of extreme insolation lows, perhaps inducing extended periods of light limitation in planktonic habitats. Careful observations of diatom assemblages provide clues to the nature of exceptional cold events only subtlety expressed in other proxies.

\section{Conclusions and future work}

From 0 to $1.2 \mathrm{Ma}$, sediments recovered from Lake El'gygytgyn record dramatic variations in diatom species assemblage and abundance. During warm interglacial intervals, both plankton and periphyton abundance increases and plankton diversity expands. Extreme warm events (MIS 11 and MIS 31) have the highest diatom concentrations observed, and abrupt plankton assemblage changes within these intervals suggest a threshold in climate-driven nutrient conditions in the lake. Exceptional cold events where plankton abundance and diversity exceed some interglacials suggest the possibility of enhanced sub-ice production promoted by periodic lake circulation and transparent ice. During some cold events, short intervals occur with extremely low plankton abundance and accumulation rates, sometimes corresponding to a shift in the dominant planktonic genus. These events are absent from intervals of lower magnitude summer insolation variation, especially $225-550 \mathrm{ka}$, suggesting a similar response seen in the Lake Baikal record.

Additional diatom studies from this interval and the complete sediment record extending to 3.6 Ma provide numerous opportunities to further test the interpretation of preliminary results presented here. Systematic observations of plankton size and preservation, and periphyton assemblages across these events, may help to distinguish open water from subice production. The patterns of diatom response may also change during earlier intervals of anticipated extreme and continuous warmth. The El'gygytgyn diatom record further provides a unique setting to observe diatom evolution linked to changing climate in this relatively isolated environment. 
Acknowledgements. Funding for this research was provided by the International Continental Scientific Drilling Program (ICDP), the US National Science Foundation (NSF, EAR-0602435 to J.A. Snyder), the German Federal Ministry of Education and Research (BMBF), Alfred Wegener Institute (AWI) and GeoForschungsZentrum Potsdam (GFZ), the Russian Academy of Sciences Far East Branch (RAS FEB, 12-1-p28-01, 12-11-sb-08-024), the Russian Foundation for Basic Research (RFBR, 12-05-00286-a to P. Minyuk), and the Austrian Federal Ministry of Science and Research (BMWF). The Russian GLAD 800 drilling system was developed and operated by DOSECC Inc. The downhole logging was performed by the ICDP-OSG, and LacCore, at the University of Minnesota, handled core curation. We thank Holger Cremer and an anonymous reviewer for their thorough reviews and suggestions.

Edited by: B. Wagner

\section{References}

Battarbee, R. W., Jones, V. J., Flower, R. J., Cameron, N. G., Bennion, H., Carvalho, L., and Juggins, S.: Diatoms, in: Tracking Environmental Change Using Lake Sediments, Vol. 3: Terrestrial, Algal, and Siliceous Indicators, edited by: Smol, J. P., Birks, H. J. B., and Last, W. M., Kluwer Academic Publishers, Dordrecht, The Netherlands, 155-202, 2001.

Bennion, H., Fluin, J., and Simpson, G. K.: Assessing eutrophication and reference conditions for Scottish freshwater lochs using subfossil diatoms, J. Appl. Ecol., 41, 124-138, 2004.

Brüchmann, C. and Negendank, J. F. W.: Indication of climatically induced natural eutrophication during the early Holocene period, based on annually laminated sediment from Lake Holzmaar, Germany, Quaternary Int., 123, 117-134, 2004.

Chapligin, B., Meyer, H., Swann, G. E. A., Meyer-Jacob, C., and Hubberten, H.-W.: A $250 \mathrm{ka}$ oxygen isotope record from diatoms at Lake El'gygytgyn, far east Russian Arctic, Clim. Past, 8, 1621-1636, doi:10.5194/cp-8-1621-2012, 2012.

Cherepanova, M. V., Snyder, J. A., and Brigham-Grette, J.: Diatom stratigraphy of the last $250 \mathrm{ka}$ at Lake El'gygytgyn, northeast Siberia, J. Paleolimnol., 37, 155-162, 2007.

Cherepanova, M. V., Usol'tseva, M. V., Pushkar, V. S., and Dubrovina, Yu. F.: Morphogenesis in Cyclotella ocellata-complex from Lake El'gygytgyn (Chukchi Peninsula) during the Pleistocene Holocene, Paleontol. J., 44, 1252-1261, 2010.

Cremer H. and van de Vijver, B.: On Pliocaenicus costatus (Bacillariophyceae) in Lake El'gygytgyn, East Siberia, Eur. J. Phycol., 41, 169-178, 2006.

Cremer, H. and Wagner, B.: The diatom flora in the ultraoligotrophic Lake El'gygytgyn, Chukotka, Polar Biol., 26, 105$114,2003$.

Cremer, H., Wagner, B., Juschus, O., and Melles, M.: A microscopical study of diatom phytoplankton in deep crater Lake El'gygytgyn, northeast Siberia, Algological Studies, 116, 147$168,2005$.

D’Anjou, R. M., Wei, J. H., Castañeda, I. S., Brigham-Grette, J., Petsch, S. T., and Finkelstein, D. B.: High-latitude environmental change during MIS 9 and 11: biogeochemical evidence from Lake El'gygytgyn, Far East Russia, Clim. Past, 9, 567-581, doi:10.5194/cp-9-567-2013, 2013.
Douglas, M. S. V. and Smol, J. P.: Freshwater diatoms as indicators of environmental change in the High Arctic, in: The Diatoms: Applications for the Environmental and Earth Sciences, edited by: Stoermer, E. F. and Smol, J. P., Cambridge University Press, Cambridge, 227-244, 1999.

Fedorov, G. B., Shvamborn, G., and Bol'shiyanov, D. Yu.: Kolebaniya urovnya ozera Elgygytgyn v pozdnechetbertichnoe vremya. Vestnik Sankt-Peterbyrgskogo Universiteta, 1, 73-78, 2008.

Fedorov, G., Nolan, M., Brigham-Grette, J., Bolshiyanov, D., Schwamborn, G., and Juschus, O.: Lake El'gygytgyn water and sediment balance components overview and its implications for the sedimentary record, Clim. Past Discuss., 8, 3977-4001, doi:10.5194/cpd-8-3977-2012, 2012.

Finkel, Z. V., Vaillancourt, C. J., Irwin, A. J., Reavie, E. D., and Smol, J. P.: Environmental control of diatom community size structure varies across aquatic ecosystems, P. Roy. Soc. B-Biol. Sci., 276, 1627-1634, 2009.

Flower, R. J., Ozornina, S. P., Kuzmina, A., and Round, F. E.: Pliocaenicus taxa in modern and fossil material mainly from eastern Russia, Diatom Res., 13, 39-62, 1998.

Frank, U., Nowaczyk, N. R., Minyuk, P., Vogel, H., Rosén, P., and Melles, M.: A $350 \mathrm{kyr}$ record of climate change from Lake El'gygytgyn, Far East Russian Arctic: refining the pattern of climate modes by means of cluster analysis, Clim. Past Discuss., 8, 5109-5132, doi:10.5194/cpd-8-5109-2012, 2012.

Gebhardt, A. C., Francke, A., Kück, J., Sauerbrey, M., Niessen, F., Wennrich, V., and Melles, M.: Petrophysical characterization of the lacustrine sediment succession drilled in Lake El'gygytgyn, Far East Russian Arctic, Clim. Past Discuss., 9, 351-391, doi:10.5194/cpd-9-351-2013, 2013.

Genkal, S. I. and Kharitonov, B. G.: Cyclotella arctica (Bacillariophyta) - novyi vid ozera El'gygytgyn (Chukotski poluostrov), Botanicheskii Zhurnal, 81, 69-73, 1996.

Genkal, S. I. and Kharitonov, B. G.: O morfologicheskoi izmenchivosti Cyclotella arctica (Bacillariophyta), Botanicheskii Zhurnal, 90, 19-22, 2005.

Genkal, S. I. and Kharitonov, B. G.: Novye dannye o redkom dlya Roccii vide Achnanthes gracillima Hust. (Bacillariophyta), Novosti cistematiki nizshikh rastenii, 40, 44-48, 2006.

Gibson, C. E., Anderson, N. J., and Haworth, E. Y.: Aulacoseira subarctica: taxonomy, physiology, ecology and palaeoecology, Eur. J. Phycol., 38, 83-101, 2003.

Grachev, M. A., Vorobyova, S. S., Likhoshway, Y. V., Goldberg, E. L., Ziborova, G. A., Levina, O. V., and Khlystov, O. M.: A highresolution diatom record of the palaeoclimates of East Siberia for the last 2.5 My from Lake Baikal, Quaternary Sci. Rev., 17, 1101-1106, 1998.

Holland, A. R., Petsch, S. T., Castañeda, I. S., Wilkie, K. M., Burns, S. J., and Brigham-Grette, J.: A biomarker record of Lake El'gygytgyn, Far East Russian Arctic: investigating sources of organic matter and carbon cycling during marine isotope stages 1-3, Clim. Past, 9, 243-260, doi:10.5194/cp-9-243-2013, 2013.

Jóuse A. P. and Sechkina T. V.: Diatomovye vodorosli v donnykh otlozheniyakh oz. El'gygytgyn (Anadyrskoe ploskogor'e), Trudy Lab. Ozerovedeniya, AN SSSR, 10, 55-62, 1960.

Juschus, O., Preusser, F., Melles, M., and Radtke, U.: Applying SAR-IRSL methodology for dating fine-grained sediments from Lake El'gygytgyn, north-eastern Siberia, Quat. Geochronol., 2, 
187-194, 2007.

Juschus, O., Pavlov, M., Schwamborn, G., Preusser, F., Federov, G., and Melles, M.: Late Quaternary lake-level changes of Lake El'gygytgyn, NE Siberia, Quaternary Res., 76, 441-451, 2011.

Kharitonov V. G.: Diatomovye vodorosli ozera El'gygytgyn (Anadyrskii raion), Botanicheskii Zhurnal, 65, 1622-1628, 1980.

Kharitonov, V. G.: K flore diatomovykh vodoroslei ozera El'gygytgyn, in: Priroda vpadiny ozera El'gygytgyn: problemy izucheniya i okhrany, edited by: Belyi, V. F. and Chereshnev, I. A., NEISRI FEB RAS, Magadan, 95-104, 1993.

Kilham, S. S., Theriot, E. C., and Fritz, S. C.: Linking planktonic diatoms and climate change using resource theory in the large lakes of the Yellowstone ecosystem, Limnol. Oceanogr., 41, 10521062, 1996.

Laskar, J., Robutel, P., Joutel, P., Gastineau, M., Correia, A. C. M., and Levrard, B.: A long-term numerical solution for the insolation quantities of the Earth, Astron. Astrophys., 428, 261-285, 2004.

Layer, P. W.: Argon-40/argon-39 age of the El'gygytgyn impact event, Chukotka, Russia, Meteor Planet. Sci., 35, 591-599, 2000.

Lisiecki, L. E. and Raymo, M. E.: A Pliocene-Pleistocene stack of 57 globally distributed benthic $\delta^{18} \mathrm{O}$ records, Paleoceanography, 20, PA1003, doi:10.1029/2004PA001071, 2005.

Lotter, A. F., Birks, H. J. B., Hofmann, W., and Marchetto, A.: Modern diatom, cladocera, chironomid, and chrysophyte cyst assemblages as quantitative indicators for the reconstruction of past environmental conditions in the Alps. II. Nutrients, J. Paleolimnol., 19, 443-463, 1998.

Lozhkin, A. V. and Anderson, P. M.: Vegetation responses to interglacial warming in the Arctic, examples from Lake El'gygytgyn, northeast Siberia, Clim. Past Discuss., 9, 245-267, doi:10.5194/cpd-9-245-2013, 2013.

Lozhkin, A. V., Anderson, P. M., Matrosova, T. V., and Minyuk, P. S.: The pollen record from El'gygytgyn Lake: implications for vegetation and climate histories of northern Chukotka since the late middle Pleistocene, J. Paleolimnol., 37, 135-153, 2007.

Melles, M., Brigham-Grette, J., Glushkova, O. Yu., Minyuk, P. S., Nowaczyk, N. R., and Hubberten, H. W.: Sedimentary geochemistry of core PG1351 from Lake El'gygytgyn - a sensitive record of climate variability in the East Siberian Arctic during the past three glacial-interglacial cycles, J. Paleolimnol., 37, 89104, 2007.

Melles, M., Brigham-Grette, J., Minyuk, P. S., Nowaczyk, N. R., Wennrich, V., DeConto, R. M., Anderson, P. M., Andreev, A. A., Coletti, A., Cook, T. L., Haltia-Hovi, E., Kukkonen, M., Lozhkin, A. V., Rosén, P., Tarasov, P., Vogel, H., and Wagner, B.: 2.8 million years of Arctic climate change from Lake El'gygytgyn, NE Russia, Science, 337, 315-320, 2012.

Meyer-Jacob, C., Vogel, H., Melles, M., and Rosén, P.: Biogeochemical properties and diagenetic changes during the past 3.6 Ma recorded by FTIR spectroscopy in the sediment record of Lake El'gygytgyn, Far East Russian Arctic, Clim. Past Discuss., 9, 2489-2515, doi:10.5194/cpd-9-2489-2013, 2013.
Nolan, M.: Analysis of local AWS and NCEP/NCAR reanalysis data at Lake El'gygtytgyn, and its implications for maintaining multi-year lake-ice covers, Clim. Past Discuss., 8, 1443-1483, doi:10.5194/cpd-8-1443-2012, 2012.

Nolan, M. and Brigham-Grette, J.: Basic hydrology, limnology, and meteorology of modern Lake El'gygytgyn, Siberia, J. Paleolimnol., 37, 17-35, 2007.

Nolan, M., Cassano, E., and Cassano, J.: Synoptic climatology and recent climate trends at Lake El'gygytgyn, Clim. Past Discuss., 8, 1485-1522, doi:10.5194/cpd-8-1485-2012, 2012.

Prokopenko, A. A., Williams, D. F., Kuzmin, M. I., Karabanov, E. B., Khursevich, G. K., and Peck, J. A.: Muted climatic oscillations in continental Siberia during the mid-Pleistocene, Nature, 418, 65-68, 2002.

Rippey, B., Anderson, N. J., and Foy, R. H.: Accuracy of diatom inferred total phosphorus concentrations and the accelerated eutrophication of a lake due to reduced flushing and increased internal loading, Can. J. Fish. Aquat. Sci., 54, 2637-2646, 1997.

Sechkina, T. V.: Novye diatomovye iz gruntov ozera El'gytkhyn Anadyrskogo raiona, Botanicheskie materialy/otdela sporovykh rastenii botanicheskogo instituta im. V.L. Komarova Akademii nauk SSSR, 11, 42-49, 1956.

Smol, J. P.: Paleoclimate proxy data from freshwater arctic diatoms, Verhandlungen International Verein Limnologie, 23, 837-844, 1988.

Stachura-Suchoples, K., Genkal, S., and Khursevich, G.: Pliocaenicus seczkinae sp. nov., from Lake El'gygytgyn in Chukotka, (NE Russia), Diatom Res., 23, 171-184, 2008.

Stoermer, E. F. and Edlund, M. B.: No paradox in the plankton? diatom communities in large lakes, in: Proceedings of the Fourteenth International Diatom Symposium, edited by: Mayama, S., Idei, M., and Koisumi, I., Koeltz Scientific Books, Koenigstein, 49-61, 1999.

van Dam, H.: On the use of measures of structure and diversity in applied diatom ecology, Nova Hedwigia, 73, 97-115, 1982.

Vogel, H., Meyer-Jacob, C., Melles, M., Brigham-Grette, J., Andreev, A. A., Wennrich, V., and Rosén, P.: Detailed insight into Arctic climatic variability during MIS 11 at Lake El'gygytgyn, NE Russia, Clim. Past Discuss., 8, 6309-6339, doi:10.5194/cpd8-6309-2012, 2012.

Wennrich, V., Francke, A., Dehnert, A., Juschus, O., Leipe, T., Vogt, C., Brigham-Grette, J., Minyuk, P. S., Melles, M., and El'gygytgyn Science Party: Modern sedimentation patterns in Lake El'gygytgyn, NE Russia, derived from surface sediment and inlet streams samples, Clim. Past, 9, 135-148, doi:10.5194/cp-9-135-2013, 2013. 